\title{
Foreign Direct Investment in Retail Industry in India
}

\author{
SP. Mathiraj, M. Thivya Bharathi, N.Nagalakshmi, Shetty Deepa Thangam Geeta
}

\begin{abstract}
The Government of India was initially very apprehensive of the introduction of the Foreign Direct Investment in the Retail Sector in India. The unorganized retail sector as has been mentioned earlier occupies $98 \%$ of the retail sector and the rest $2 \%$ is contributed by the organized sector. The unorganized retail sector contributes about $14 \%$ to the GDP and absorbs about $7 \%$ of our labor force. Retail is the sale of goods to end users, not for resale, but for use and consumption by the purchaser. The retail transaction is at the end of the supply chain. Manufacturers sell large quantities of products to retailers, and retailers sell small quantities of those products to consumers. This study has been undertaken foreign direct investment has affected the Indian retail industry. The inflow of foreign direct investment has boosted growth in the retail industry and increased the gross domestic product of India. Government policy and other determinants have been discussed to study and analyze the impact. The Indian retail market is a developing market and has potential for investments. There had been a restriction in the inflow of foreign direct investment till 2006. But since 2006, there has been a positive change in the government policy thereby allowing foreign companies to invest in India and become an owner. The paper elucidates the growth between different sectors of Indian retail industry, the tax incentives and determinants for inflow of foreign direct investment. This study focuses on foreign direct investment inflows in selected retail sectors.
\end{abstract}

Keywords: FDI, Retail, GDP, Government Policy, Foreign Companies.

\section{INTRODUCTION}

Foreign Direct Investment is the investment made in production or business by the country in another country by either means of buying a company or expanding its business in the foreign country. It is usually by means of bonds and shares. Generally speaking, FDI refers to capital inflows from abroad that invest in the production capacity of the economy and are "usually preferred over other forms of external finance because they are non-debt creation, non-volatile and their returns depend on the

Revised Manuscript Received on October 15, 2019.

* Correspondence Author

Dr. SP. Mathiraj, Associate Professor, Department of Corporate Secretaryship, Alagappa University, Karaikudi, Tamilnadu, India.

M. Thivya Bharathi, Ph. D Research Scholar, Department of Corporate Secretaryship, Alagappa University, Karaikudi, Tamilnadu, India

N.Nagalakshmi, Ph. D Research Scholar, Department of Corporate Secretaryship, Alagappa University, Karaikudi, Tamilnadu, India

Shetty Deepa Thangam Geeta, Ph. D Research Scholar, Department of Commerce, Alagappa University, Karaikudi, Tamilnadu, India performance of the projects financed by the investors. FDI also facilitates international trade and transfer of information, skills and technology. "Standard definitions of control use the internationally agreed 10 percent threshold of voting shares, but this is a grey area as often a smaller block of shares will provide control in widely held companies. Moreover, management of technology, management, even crucial inputs can confer de facto control."

\section{REVIEW OF LITERATURE}

Sutherland, Dylan, Hennart, Jean-Francois \& Anderson, John R. (2019) ${ }^{1}$ an extensive empirical literature tests the motivations and characteristics of the outward foreign direct investments of Chinese MNEs. Much of it, however, suffers from serious shortcomings in its treatment and use of foreign direct investment information.

In particular, most research fails to properly account for the ways in which Chinese MNEs route their foreign direct investments both to and via tax havens and financial centers. As a result, our understanding the Chinese MNEs still remains embryonic. We define the nature of the most commonly found problems so as to inform future research.

\section{NEED FOR THE STUDY}

Foreign Direct Investment (FDI) has become an integral part of national development strategies for nearly all the nations globally. FDI in India has contributed effectively to the overall growth of the economy in the recent times. FDI inflow has an impact on India's transfer of new technology and innovative ideas; improving infrastructure, thus makes a competitive business environment.

\section{OBJECTIVES}

- To analyze the growth across different segment in the retail industry.

- To study the trend analysis of the selected retail sectors.

- To examine the growth of FDI inflows of selected retail sectors. 


\section{RESEARCH METHODOLOGY}

This study consists of secondary data. The Secondary data have been collected from published and unpublished reports, handbooks, action plan, Text Books, Journals, Magazines, and FDI Statistics.

\section{SCOPE OF STUDY}

The purpose of the paper is to study the impact of FDI in retail industry for the past ten years. Our scope of study has been restricted to five sectors. The basis of selecting these five sectors is the ranking among the top sectors in terms of amount of foreign direct investment inflow. The data has been collected for the past 10 years only as the retail industry has undergone significant transformation since then. Indian retail industry was largely dominated by small unorganized sector before globalization and introduction of FDI in India.

\section{HYPOTHESIS}

H01: There is no significant growth among different retail sectors with respect to FDI inflow.
H02: There is significant growth among different retail sectors with respect of FDI inflow.

\section{LIMITATIONS}

The research paper is narrowed down to only growth aspect for retailing in India. Any aspects about the other sectors have not been taken into consideration.

\section{DATA ANALYSIS AND INTERPRETATION}

A trend analysis on the total foreign direct investment inflow in the country has been studied. The trend concludes that there has been an increase in foreign direct investment. The raise in foreign direct investments has been from 2006 but it boosted from 2012. The reason for the boost is the change in government policy, India emerging as global marker and advancing technology. In 2012, Government has increased the foreign direct investment inflow from $51 \%$. The multi brand retail was restricted to inflow of foreign direct investment in India before 2012.

Table 1:FDI Equity Inflows of Computer Software \& Hardware

\begin{tabular}{|c|c|c|c|c|c|c|c|c|c|c|}
\hline \multicolumn{11}{|c|}{ Retail Sector } \\
\hline Years & $\begin{array}{c}\text { Compute } \\
\text { r } \\
\text { Software } \\
\& \\
\text { Hardwar } \\
\text { e }\end{array}$ & $\begin{array}{c}\text { Growt } \\
\text { h } \%\end{array}$ & $\begin{array}{c}\text { Housing } \\
\text { \& Real } \\
\text { Estate }\end{array}$ & $\begin{array}{c}\text { Growt } \\
\text { h \% }\end{array}$ & $\begin{array}{c}\text { Powe } \\
\mathbf{r}\end{array}$ & $\begin{array}{c}\text { Growt } \\
\text { h } \%\end{array}$ & $\begin{array}{c}\text { Petroleum } \\
\text { \& Natural } \\
\text { Gas }\end{array}$ & $\begin{array}{c}\text { Growth } \\
\%\end{array}$ & $\begin{array}{l}\text { Automo } \\
\text { bile } \\
\text { Sector }\end{array}$ & $\begin{array}{c}\text { Growt } \\
\text { h } \%\end{array}$ \\
\hline 2009-10 & 4,350 & _ & 5,149 & - & 6,908 & & 1,328 & & 5754 & \\
\hline $2010-11$ & 3,571 & -17.90 & 5,600 & 8.75 & 5,709 & -17.35 & 2,621 & 97.36 & 4805 & -16.49 \\
\hline 2011-12 & 4,350 & 6.52 & 3,443 & -38.51 & 7,678 & 34.48 & 9012 & 243.83 & 4347 & -9.53 \\
\hline 2012-13 & 3,804 & 591.53 & 6011 & 74.58 & 7248 & -5.60 & 1654 & -81.64 & 8384 & 92.86 \\
\hline 2013-14 & 26306 & -49.46 & 7191 & 19.63 & 7508 & 3.58 & 502 & -69.64 & 9027 & 7.66 \\
\hline 2014-15 & 13,294 & 105.87 & 9052 & 25.87 & 4652 & -38.03 & 17372 & 3360.55 & 16760 & 85.66 \\
\hline $2015-16$ & 27,369 & 0.95 & 2267 & -74.95 & 673 & -85.53 & 6936 & -60.07 & 11405 & -31.95 \\
\hline 2016-17 & 27,630 & 110.69 & 5723 & 152.44 & 703 & 4.45 & 37435 & 439.72 & 10824 & -5.09 \\
\hline 2017-18 & 58,214 & -25.70 & 6502 & 13.61 & 3472 & 393.88 & 39748 & 6.178 & 13461 & 24.36 \\
\hline 2018-19 & 43,249 & 47.76 & 1842 & -71.67 & 1503 & -56.71 & 18337 & -53.86 & 18309 & 36.01 \\
\hline
\end{tabular}

Source: FDI Annual Report

The table 1 the FDI inflows Computer Software \& Hardware in highest growth rate is $591.53 \%$ of the year 2012-2013. There is fluctuation in annual growth rate and during 2014-2015 and 2015-2016 there is $-17.90 \%,-49.46$ and $-25.70 \%$ negative growth rate due to FDI Retail industries in the respective years.

FDI inflows Housing \& Real Estate in highest growth rate is $152.44 \%$ of the year 2016-2017. There is fluctuation in annual growth rate and during 2012-13 and 2013-14 there is $-74.95 \%$, and $-71.67 \%$ negative growth rates due to FDI Retail industries in the respective years.

FDI inflows Power in highest growth rate is $393.88 \%$ of the year 2017-2018. There is fluctuation in annual growth rate and during $2012-13$ to $2016-17$ there is $-5.60 \%$,

$38.03 \%,-85.53 \%$ and $-56.71 \%$ negative growth rate due to FDI Retail industries in the respective years.

FDI inflows Petroleum \& Natural Gas in highest growth rate is $3360.55 \%$ of the year 2014-2015. There is fluctuation in annual growth rate during the year of 2012-13 to 2016-17 and there is $-81.67 \%,-69.64 \%,-60.07 \%$, and $-53.86 \%$ negative growth rate due to FDI Retail industries in the respective years.

FDI inflows Automobile Sector in highest growth rate is $152.44 \%$ of the year 2016-2017. There is fluctuation in annual growth rate and during 2012-13 and 2013-14 there is $-74.95 \%$, and $-71.67 \%$ negative growth rates due to FDI Retail industries in the respective years. 
Table 2: Descriptive analysis for Retail Sectors

\begin{tabular}{|c|c|c|c|c|c|}
\hline \multicolumn{7}{|c|}{ Statistics } & Automobile Sector \\
\hline Mean & $\begin{array}{c}\text { Computer } \\
\text { Software \& } \\
\text { Hardware }\end{array}$ & $\begin{array}{c}\text { Housing \& } \\
\text { Real Estate }\end{array}$ & Power & $\begin{array}{c}\text { Petroleum \& Natural } \\
\text { Gas }\end{array}$ & 10307.6 \\
\hline $\begin{array}{c}\text { Standard } \\
\text { Error }\end{array}$ & 6983.468198 & 703.1351 & 900.4526 & 4641.89205 & 1523.714615 \\
\hline Median & 26837.5 & 5661.5 & 5180.5 & 7974 & 9925.5 \\
\hline $\begin{array}{c}\text { Standard } \\
\text { Deviation }\end{array}$ & 22083.66547 & 2223.508 & 2847.481 & 14678.9515 & 4818.408686 \\
\hline $\begin{array}{c}\text { Sample } \\
\text { Variance }\end{array}$ & 487688280.7 & 4943989 & 8108149 & 215471618 & 23217062.27 \\
\hline Kurtosis & -0.91276581 & -0.3055 & -1.67077 & -0.1525187 & -0.87413839 \\
\hline Skewness & 0.557277785 & -0.13824 & -0.39755 & 1.08359249 & 0.411814109 \\
\hline Range & 60338 & 7210 & 7005 & 39246 & 13962 \\
\hline Minimum & 3571 & 1842 & 673 & 502 & 4347 \\
\hline Maximum & 63909 & 9052 & 7678 & 39748 & 18309 \\
\hline Sum & 271696 & 52780 & 46054 & 134945 & 103076 \\
\hline
\end{tabular}

The table 2 shows Mean, Std. Error of Mean Median, Mode, Median, Std. Deviation, Variance, Skewness, Std. Error of
Skewness, Kurtosis \& Std. Error of Kurtosis calculation of Total Retailer Sectors.

Table 3: Two-way ANOVA of Retail Industries Sector

\begin{tabular}{|c|c|c|c|c|c|}
\hline $\begin{array}{c}\text { Source of } \\
\text { Variation }\end{array}$ & Sum of Square & Df & Mean Square & F & P-value \\
\hline Between Years & 2010016546 & 8 & 251252068.2 & 2.07 & 0.07 \\
\hline Between sectors & 3793396755 & 4 & 948349188.8 & 7.83 & 0.00 \\
\hline Residual & 3872832296 & 32 & 121026009.2 & & \\
\hline Total & $\mathbf{9 6 7 6 2 4 5 5 9 7}$ & $\mathbf{4 4}$ & & & \\
\hline
\end{tabular}

Table 3 shows the TWO WAY ANOVA on the growth rate of foreign direct investment of 5 selected industries under single retail industry. After interpreting the results of the test, we conclude that the null hypothesis is true. There has been no significant change in the growth rate of these 5 sectors. The study proves that the sigma is more than $5 \%$ which is $0.07 \%$. The reasons for the same could be because of the foreign direct investment in this segment are $100 \%$.

\section{FINDINGS AND SUGGESTIONS}

1. Foreign direct investment has a significant impact on the growth and development of the industry.

2. The FDI inflow in the retail sector has increased during the last 10 years.

3. Through this paper it has been observed that there is no significant growth among the sectors chosen.

4. The analysis has resulted in determining the relationship between the five sectors of the Indian retail industry over a period of 10 years, the changes in FDI distribution among the sectors is normal.

The scope of the Study can be increased by analyzing the other sectors of multi-brand and single brand retail. The tax incentives provided by the government and the tax policies of the countries investing in India can be analyzed to understand the restrictions of investing in India.

\section{CONCLUSION}

India retail sector has grown by leaps and bounds in the recent years. The growth and employment rates in terms of FDI in form of direct and institutional investment have been increasing at a phenomenal rate. Starting from the colonial period to the modern era, the impact FDI has on the Indian economy has changed tremendously. The changes in the government policies, introduction and adoption of technology, availability of labour and capital have contributed to high performance of the Indian retail industry which in turn has increased the FDI inflow in the country. This has resulted in the diversification, expansion and introduction of various businesses in the retail industry. The amendment of 2012, to allow 51\% FDI in multi- brand retail and the recent policy allowing $100 \%$ FDI in single brand retail through automatic route has lead to reduced prices and better management of inflation, creation of employment, induced investment and enabled the small and medium enterprise to expand their market. 
The project enables to understand the role of FDI in the development of the retail sector in the past years. Thus based on the calculations and analysis it is determined that FDI is a great boost to the Indian economy.

\section{REFERENCES}

1. http://ijrar.org/papers/IJRAR190I021.pdf

2. https://www.mbarendezvous.com/general-awareness/why-fdi-is-needed-i n-india

3. http://dipp.nic.in/publications/fdi-statistics

4. https://community.data.gov.in/total-foreign-direct-investment-equity-infl ows-from2000-01-to-2016-17/

5. https://flexiloans.com/blog/fdi-impact-retail-sector-india/

6. http://www.legalservicesindia.com/article/1473/FDI-in-Retail-Sector.ht $\mathrm{ml}$

7. Sutherland, Dylan, (2019). How does the routing of FDI to and via tax havens confound our understanding of Chinese MNE identity? a critical review of the empirical literature on Chinese MNEs. 